\title{
Estimation of endogenous protein and amino acid ileal losses in weaned piglets by regression analysis using diets with graded levels of casein
}

Tércia Cesária Reis de Souza ${ }^{1}$, Araceli Aguilera Barreyro ${ }^{1}$ and Gerardo Mariscal-Landín ${ }^{*}$

\begin{abstract}
Background: Many studies have investigated endogenous loss of proteins and amino acids (AAs) at the ileal level in growing pigs. However, only a few studies have researched this subject in piglets. Knowledge regarding AA ileal digestibility in piglets would be helpful during the formulation of diets for weaning piglets, rather than just using coefficients obtained in growing pigs. Therefore, in this study, we sought to estimate endogenous protein and AA ileal losses in piglets. Furthermore, apparent and true ileal digestibility (AID and TID) of protein and AAs from casein were measured.

Results: The average flow of protein was $20.8 \mathrm{~g} / \mathrm{kg}$ of dry matter intake (DMI). Basal protein loss, as estimated by regression, was $16.9 \mathrm{~g} / \mathrm{kg}$ DMI. Glutamic acid, arginine, and aspartic acid (2.2, 1.4, and $1.2 \mathrm{~g} / \mathrm{kg}$ DMl, respectively) were the AAs for which greater losses were seen. The AID of protein and AAs increased as the protein level in the diet increased. A higher increment in AID was observed between diets with 80 and $160 \mathrm{~g} \mathrm{CP} / \mathrm{kg}$ of feed; this finding was mainly attributable to increases in glycine and arginine (46.1\% and $18 \%$, respectively). The TID of protein was 97.8, and the TID of AAs varied from 93.9 for histidine to 100.2 for phenylalanine.
\end{abstract}

Conclusions: The basal endogenous protein loss in piglets was $16.9 \mathrm{~g} / \mathrm{kg}$ DMI. Endogenous protein was rich in glutamic acid, aspartic acid, and arginine, which represented 32.7\% of endogenous protein loss in weaning piglets. The TID of casein was high and varied from 93.0 for histidine to 100.2 for phenylalanine.

Keywords: Amino acid loss, lleal digestibility, Protein loss, Weaned piglets

\section{Background}

Many studies have investigated endogenous loss of proteins and amino acids (AAs) at the ileal level in growing pigs [1-3]. However, only a few studies have researched this subject in piglets [4-7]. Mariscal-Landín and Reis de Souza [6] reported high proline endogenous losses following prolonged intake $(15 \mathrm{~d})$ of a low protein diet in piglets, and similar effects of low protein or protein-free diets have been reported in growing pigs $[1,8,9]$. Further knowledge regarding AA ileal digestibility in piglets would be helpful during the formulation of diets for weaning piglets, rather than just using coefficients obtained from data for optimal diets in growing pigs, especially for

\footnotetext{
* Correspondence: mariscal.gerardo@inifap.gob.mx

${ }^{2}$ Centro Nacional de Investigación en Fisiología Animal, Instituto Nacional de Investigaciones Forestales Agrícolas y Pecuarias, Km 1, Carretera a Colón, Ajuchitlán Colón Querétaro, 76280 México

Full list of author information is available at the end of the article
}

cereals and vegetable proteins $[10,11]$. In order to achieve this goal, it is essential to determine the endogenous loss of protein and AAs in the ileum of piglets.

Therefore, the objectives of this study were: 1) measure endogenous ileal loss of protein and AAs in weaned piglets, avoiding changes in the AA profile of endogenous protein through prolonged intake of a low protein diet; 2) measure the apparent and true ileal digestibility (AID and TID, respectively) of protein and AAs derived from casein.

\section{Materials and methods}

The experiment was performed at the experimental farm of CENID-Physiology. The care of animals used in this study was in accordance with the guidelines issued by the Mexican Official Standard for the Production, Protection and Use of Lab Animals [12] and the guidelines of the International Guiding Principles for Biomedical Research Involving Animals [13]. 


\section{Animals}

Eighteen piglets (Duroc $\times$ Landrace; 6 per group), weaned at $18 \pm 1 \mathrm{~d}$ of age and weighing $6 \pm 1 \mathrm{~kg}$, were used. The piglets were placed in individual metabolism cages provided with a self-feeder and a low pressure drinking nipple, in a temperature controlled room (26 \pm $3^{\circ} \mathrm{C}$ ). In order to modify the enzymatic profile of suckling animals as little as possible; piglets were fed from 18 to $20 \mathrm{~d}$ of age with a mixture of dry whole milk (80\%) and maize starch (20\%) 3 times/d, at 0800, 1300 and $1800 \mathrm{~h}$, at a concentration of $30 \mathrm{~g} / \mathrm{kg}$ body weight (BW). When the piglets were $21 \mathrm{~d}$ old, a $\mathrm{T}$ cannula was fit at the terminal ileum as previously described [14]. After surgery, a therapeutic treatment (penicillin 600,000 IU, streptomycin $750 \mathrm{mg}$, oxytetracycline $500 \mathrm{mg}$ ) was administered for $3 \mathrm{~d}$, and the piglets received a casein diet containing $240 \mathrm{~g}$ of crude protein $(\mathrm{CP}) / \mathrm{kg}$ for $8 \mathrm{~d}$.

\section{Experimental diets}

From the ninth $\mathrm{d}$ after surgery, piglets received 1 of 3 experimental treatments (Table 1). Casein was used as the sole protein source to provide 80,160 or $240 \mathrm{~g}$ of $\mathrm{CP} / \mathrm{kg}$

Table 1 Experimental diets composition ( $\mathrm{g} / \mathbf{k g}$ feed $^{\mathbf{1}}$ )

\begin{tabular}{|c|c|c|c|}
\hline g CP/kg feed & 80 & 160 & 240 \\
\hline Maize starch & 677.3 & 604.2 & 523.3 \\
\hline Casein & 89.8 & 180.0 & 270.1 \\
\hline Lactose & 126.3 & 126.3 & 126.3 \\
\hline Maize oil & 40.0 & 40.0 & 40.0 \\
\hline \multicolumn{4}{|l|}{ Calcium Phosphate } \\
\hline (dicalcium) & 32.1 & 27.9 & 23.8 \\
\hline Calcium carbonate & & 1.1 & 2.1 \\
\hline Salt & 6.4 & 6.4 & 6.4 \\
\hline Vitamins $^{2}$ & 3.6 & 3.6 & 3.6 \\
\hline Minerals ${ }^{3}$ & 1.2 & 1.2 & 1.2 \\
\hline Antioxidant ${ }^{4}$ & 0.2 & 0.2 & 0.2 \\
\hline Chromic oxide & 3.0 & 3.0 & 3.0 \\
\hline Lysine $\mathrm{HCl}$ & 1.7 & & \\
\hline Tryptosine ${ }^{5}$ & 9.1 & 2.7 & \\
\hline DL Methionine & 4.5 & 1.9 & \\
\hline L Threonine & 4.8 & 1.5 & \\
\hline Protein, g/kg ${ }^{6}$ & 98.0 & 151.3 & 231.5 \\
\hline $\mathrm{ED}, \mathrm{MJ} \cdot \mathrm{kg}^{7}$ & 15.1 & 15.1 & 15.1 \\
\hline $\begin{array}{l}{ }^{1} \text { As fed basis. } \\
{ }^{2} \text { Vitamin premix that } \\
10,200 \text { IU, D 1,980 IU, } \\
\text { Pantothenic acid } 17 \mathrm{~m} \\
0.30 \mathrm{mg} \text {, Pyridoxine } 0 \\
{ }^{3} \text { Mineral premix that } \\
\text { Fe } 120 \mathrm{mg}, \mathrm{Mn} 36 \mathrm{mg}, \\
{ }^{4} \text { ANTI-OX-HP, Compa } \\
{ }^{5} 15 / 70 \text { Tryptophan/L } \\
{ }^{6} \text { Analyzed levels. } \\
{ }^{7} \text { Estimated from INRA }\end{array}$ & $\begin{array}{l}\text { er kilogr } \\
.20 \mathrm{mg} \text {, } \\
\text { in } 7.2 \mathrm{~m} \\
\text { in } 0.08 \\
\text { kilograr } \\
\text { Zn } 144 \mathrm{n} \\
\text { que d'Aq }\end{array}$ & $\begin{array}{l}\text { t diet: Vi } \\
\mathrm{mg}, \mathrm{Ni} \\
1240 \mu \mathrm{g} \\
\text { id } 0.75 \mathrm{r} \\
\text { liet: } \mathrm{Cu} 1\end{array}$ & 96 mg, \\
\hline
\end{tabular}

of feed. Because the low protein diets used in this study ( 80 or $160 \mathrm{~g} \mathrm{CP} / \mathrm{kg}$ ) did not provide sufficient levels of lysine, methionine, threonine, or tryptophan, these AAs were supplemented to fulfill NRC nutrient requirements (Table 2) [15]. All 3 experimental diets contained the same amount of lactose and maize oil. To adjust calcium and phosphorus levels, calcium carbonate and dicalcium phosphate were used. Salt and vitamin and mineral premixes were included at levels that met or exceeded the NRC nutritional requirements [15]. Chromic oxide was added at a rate of $3 \mathrm{~g} / \mathrm{kg}$ of feed as an inert marker.

\section{Sample collection}

Experimental diets were supplied starting on d 9 after surgery, according to schedules described previously. The experimental period lasted for $7 \mathrm{~d}$, that is $5 \mathrm{~d}$ for adaptation and $2 \mathrm{~d}$ for collection of ileal digesta. Feed intake was fixed at $26 \mathrm{~g} / \mathrm{kg} \mathrm{BW}$ during the experimental period to maintain feed intake at a constant level in relation to BW for all animals. The piglets always had free access to water.

Ileal digesta were collected in plastic bags $(5 \mathrm{~cm} \times 3 \mathrm{~cm})$ containing $2 \mathrm{~mL}$ of a $0.2 \mathrm{~mol} / \mathrm{L}$ solution of $\mathrm{HCl}$ to minimize further bacterial activity. Bags were attached to the barrel of the cannula with a rubber band. Ileal digesta were collected continuously over the course of $12 \mathrm{~h}$ when the piglets were 36 and 37 d of age (d 16 and 17 after surgery).

Table 2 Protein and amino acids composition of experimental diets (g/kg DM)

\begin{tabular}{lccc}
\hline $\mathbf{g ~ C P / k g}$ feed & $\mathbf{8 0}$ & $\mathbf{1 6 0}$ & $\mathbf{2 4 0}$ \\
\hline Protein & 105.0 & 162.0 & 247.0 \\
Essential amino acids & & & \\
Arginine & 3.4 & 6.2 & 10.2 \\
Histidine & 2.6 & 4.9 & 7.8 \\
Lysine & 13.8 & 14.2 & 19.8 \\
Isoleucine & 4.6 & 8.6 & 14.1 \\
Leucine & 8.2 & 15.3 & 24.9 \\
Valine & 5.8 & 10.9 & 17.7 \\
Methionine & 7.0 & 7.5 & 6.9 \\
Phenylalanine & 4.7 & 8.6 & 15.1 \\
Threonine & 9.8 & 10.8 & 12.0 \\
Non essential amino acids & & & \\
Alanine & 2.8 & 5.2 & 8.4 \\
Aspartic acid & 6.2 & 11.5 & 18.9 \\
Cystine & 0.6 & 0.9 & 1.4 \\
Glutamic acid & 20.0 & 37.7 & 62.1 \\
Glycine & 1.8 & 3.4 & 5.3 \\
Proline & 8.2 & 17.3 & 23.7 \\
Serine & 4.8 & 9.0 & 14.8 \\
Tyrosine & 4.4 & 8.1 & 14.2 \\
\hline
\end{tabular}


When ileal digesta filled the bags, they were transferred to a container and frozen at $-20^{\circ} \mathrm{C}$ until lyophilization.

\section{Preparation of samples and chemical analysis}

Ileal digesta were lyiophilized and ground in a laboratory mill by using a $0.5-\mathrm{mm}$ mesh (Arthur H. Thomas Co. Philadelphia, PA). Experimental diets and ileal digesta were analyzed for dry matter (DM) and CP, according to AOAC methods 934.01 and 976.05 [17] respectively, and for chromic oxide according to the methods reported by Fenton and Fenton [18]. Sample preparation for AA analysis was performed following method 994.12 of AOAC [17], samples were hydrolysed in $6 \mathrm{~mol} / \mathrm{L} \mathrm{HCl}$ at $110^{\circ} \mathrm{C}$ for $24 \mathrm{~h}$. Methionine and cystine were oxidized with performic acid before analysis [17]. Amino acids analysis was performed according to the method reported by Henderson et al. [19]. Tryptophan was not analyzed.

\section{Data analysis}

Endogenous protein and AA losses in the ileal digesta were estimated using the following equation [20]:

$$
I L A A=A F \times(I D / I F)
$$

Where ILAA is the ileal loss of CP or AA expressed in $\mathrm{g} / \mathrm{kg} \mathrm{DMI}, A F$ is the nutrient concentration in ileal digesta $(\mathrm{g} / \mathrm{kg} \mathrm{DM}), I D$ is the marker concentration in the diet $(\mathrm{g} / \mathrm{kg} \mathrm{DM})$, and $I F$ is the marker concentration in the ileal digesta $(\mathrm{g} / \mathrm{kg} \mathrm{DM})$.

The AIDs of DM, protein and AAs were estimated using the following equation [20]:

$$
A I D=[1-[(I D \times A F) /(A D \times I F)]] \times 100
$$

Where $A I D$ is the apparent ileal digestibility of a nutrient in the diet, $I D$ is the marker concentration in the diet (g/kg DM), $A F$ is the nutrient concentration in the ileal digesta $(\mathrm{g} / \mathrm{kg} \mathrm{DM}), A D$ is the nutrient concentration in diet $(\mathrm{g} / \mathrm{kg} \mathrm{DM})$, and $I F$ is the marker concentration in the ileal digesta $(\mathrm{g} / \mathrm{kg} \mathrm{DM})$. The calculi excluded crystalline amino acids (L-Lys-HCl, DL-Met, L-Thr and L-Trp) because they were considered completely digested at the end of the ileum [21,22].

Basal protein and AA ileal losses and the TIDs of protein and AAs from casein were estimated by linear regression [2]:

$$
y=a+b x
$$

Where $y$ is the protein or amino acid amount disappearing from the digestive tract in terms of $\mathrm{g} / \mathrm{kg}$ DMI, $a$ is the protein or amino acid basal ileal loss in terms of $\mathrm{g} / \mathrm{kg} \mathrm{DMI}, b$ is the protein or amino acid disappearing in the digestive tract, (equivalent to the TID), and $x$ is the intake in $\mathrm{g} / \mathrm{kg}$ DMI. Regression was performed using the REG procedure of the SAS software
[23]. Performing regression analysis in this way allowed us to obtain a high value of the regression coefficient $R^{2}$, because almost the total amount of nutrient ingested disappeared at the ileal level. The intercept was negative because an endogenous loss was, by definition, an amount found at zero intake, and consequently, at zero intake there was no dietary nutrient absorption, only excretion. Nevertheless, the absolute value of the intercept using excreted (non-digestible) or absorbed (digestible) nutrient was the same and could be used as reported previously [2].

\section{Statistical analysis}

Homogeneity of variance for all data was tested by Levene's test using the hovtest of the SAS software [23]. Protein and AA Ileal losses and AID data were analyzed as a completely randomized design under the general model:

$$
Y i j=\mu+T i+e i j
$$

Where $Y_{i j}$ is the dependent variable; $\mu$ is the general mean; $T_{i}$ is the treatment $1,2,3$; and $e_{i j}$ is the experimental error, calculated using the GLM procedure of the SAS software [23]. The piglets were the experimental units for all analyses. Treatment means were compared using the Duncan method, an $\alpha$-value of 0.05 was used to assess significance and orthogonal polynomial contrast were performed to find a linear or quadratic response [24].

\section{Results}

\section{Protein and amino acids flow at ileal level}

Protein flow was higher in the digesta of piglets fed $160 \mathrm{~g}$ $\mathrm{CP} / \mathrm{kg}$ of feed than in the digesta of piglets fed $80 \mathrm{~g} \mathrm{CP} / \mathrm{kg}$ of feed $(P<0.05$, Table 3$)$. Moreover, significant differences among these groups were observed for the AAs valine $(P<$ $0.05)$, threonine $(P<0.05)$, aspartic acid $(P<0.05)$, glutamic acid $(P<0.05)$, serine $(P<0.01)$ and histidine $(P<0.001)$. Protein flow was similar between digesta of piglets fed 160 or $240 \mathrm{~g} \mathrm{CP} / \mathrm{kg}$ of feed $(P>0.05)$.

For all 3 groups, the average protein flow was $20.8 \mathrm{~g} / \mathrm{kg}$ DMI. Protein was rich in glutamic acid, aspartic acid, arginine and threonine $(3.2 ; 1.6 ; 1.4$ and $1.3 \mathrm{~g} / \mathrm{kg} \mathrm{DMI}$, respectively). These amounts represented 17.6\%, 8.7\%, 7.9\% and $7.0 \%$ of total AAs. AAs with lower flow included methionine, histidine and tyrosine $(0.3,0.5$, and $0.5 \mathrm{~g} / \mathrm{kg}$ DMI, respectively); these flow represented 1.6\%, 3.0\%, and $3.1 \%$ of total AA flow, respectively.

\section{Basal endogenous losses}

The basal endogenous protein ileal loss estimated by regression was $16.9 \mathrm{~g} / \mathrm{kg}$ DMI (Table 4). Glutamic acid, arginine and aspartic acid were the AAs exhibiting larger basal endogenous ileal losses (2.2, 1.4, and $1.2 \mathrm{~g} / \mathrm{kg}$ DMI, respectively). AAs with lower endogenous losses included histidine, methionine, and tyrosine $(0.2,0.4$ and $0.5 \mathrm{~g} / \mathrm{kg}$ 
Table 3 Protein and amino acids flow at the ileum level, in terms of dry matter intake $(\mathrm{g} / \mathrm{kg})$

\begin{tabular}{|c|c|c|c|c|c|}
\hline $\mathrm{g} \mathrm{CP} / \mathrm{kg}$ feed & 80 & 160 & 240 & SEM $^{1}$ & $P$ value $^{2}$ \\
\hline Protein $^{c}$ & $17.67^{a}$ & $22.10^{\mathrm{b}}$ & $22.72^{b}$ & 0.77 & 0.05 \\
\hline \multicolumn{6}{|c|}{ Essential amino acids } \\
\hline Arginine & 1.25 & 1.56 & 1.47 & 0.06 & NS \\
\hline Histidine $^{B}$ & $0.36^{a}$ & $0.52^{b}$ & $0.74^{b}$ & 0.04 & 0.001 \\
\hline Lysine & 0.61 & 0.74 & 0.71 & 0.04 & NS \\
\hline Isoleucine ${ }^{B}$ & $0.65^{\mathrm{a}}$ & $0.88^{b}$ & $0.93^{b}$ & 0.03 & 0.01 \\
\hline Leucine $^{E}$ & 0.91 & 1.17 & 1.11 & 0.04 & NS \\
\hline Valine $^{B}$ & $0.81^{\mathrm{a}}$ & $1.08^{\mathrm{b}}$ & $1.11^{\mathrm{b}}$ & 0.04 & 0.05 \\
\hline Methionine & 0.30 & 0.31 & 0.25 & 0.02 & NS \\
\hline Phenylalanine ${ }^{\mathrm{E}}$ & 0.55 & 0.67 & 0.60 & 0.03 & NS \\
\hline Threonine $^{B}$ & $1.01^{\mathrm{a}}$ & $1.34^{\mathrm{b}}$ & $1.43^{b}$ & 0.05 & 0.05 \\
\hline \multicolumn{6}{|c|}{ Non essential amino acids } \\
\hline Alanine $^{\mathrm{D}}$ & 0.97 & 1.24 & 1.22 & 0.05 & NS \\
\hline Aspartic acid ${ }^{C}$ & $1.26^{\mathrm{a}}$ & $1.77^{\mathrm{b}}$ & $1.73^{\mathrm{b}}$ & 0.08 & 0.05 \\
\hline Cystine & 0.32 & 0.37 & 0.39 & 0.05 & NS \\
\hline Glutamic acid $^{C}$ & $2.33^{a}$ & $3.65^{b}$ & $3.76^{b}$ & 0.21 & 0.05 \\
\hline Glycine & 0.94 & 0.97 & 1.02 & 0.04 & NS \\
\hline Proline $^{\mathrm{D}}$ & 1.03 & 1.37 & 1.40 & 0.08 & NS \\
\hline Serine $^{A}$ & $1.04^{\mathrm{a}}$ & $1.49^{\mathrm{b}}$ & $1.69^{\mathrm{b}}$ & 0.06 & 0.01 \\
\hline Tyrosine $e^{E}$ & 0.49 & 0.61 & 0.55 & 0.03 & NS \\
\hline
\end{tabular}

1 Standard error of the mean.

${ }^{2 a b}$ Means with different superscript differ at probability level show in the fifth column

NS non significant.

${ }^{A}$ Linear effect $(P<0.001),{ }^{B}$ Linear effect $(P<0.01),{ }^{C}$ Linear effect $(P<0.05)$,

${ }^{\mathrm{D}}$ Linear effect $(P<0.10)$, ${ }^{\mathrm{E}}$ Quadratic effect $(P<0.10)$.

DMI, respectively). All regressions were significant $(P<$ 0.001 ) and had determination coefficients of at least 0.98 .

\section{AID}

The AIDs of protein, arginine, leucine, isoleucine, valine, phenylalanine, methionine, aspartic acid, serine, glycine, alanine and tyrosine, increased as casein levels increased (Table 5). The AIDs of histidine, cystine and proline differed significantly between piglets fed 80 and $160 \mathrm{~g} \mathrm{CP} / \mathrm{kg}$ feed, while the AIDs of these AAs were similar between piglets fed 160 and $240 \mathrm{~g} \mathrm{CP} / \mathrm{kg}$ of feed. The AID of lysine was different between piglets consuming 80 and $240 \mathrm{~g} \mathrm{CP} / \mathrm{kg}$, and the AID observed in piglets fed with $160 \mathrm{~g} \mathrm{CP} / \mathrm{kg}$ was similar to those of the other 2 treatments. The AID of glutamic acid was similar in piglets consuming 80 and $160 \mathrm{~g} \mathrm{CP} / \mathrm{kg}$ and lower than that in piglets consuming $240 \mathrm{~g} \mathrm{CP} / \mathrm{kg}$. However, all amino acids and protein showed a linear increment $(P<0.01)$ in their AIDs as protein level increased in the diet.

The AAs with the greatest differences in their AIDs between piglets consuming 80 and $160 \mathrm{~g} \mathrm{CP} / \mathrm{kg}$ were glycine (46.1\%), arginine (18\%), valine (16.3\%) and alanine (14.4\%).
Table 4 Basal ileal losses (g/kg DMI) and true ileal digestibility estimated by regression ${ }^{1}$

\begin{tabular}{|c|c|c|c|c|c|}
\hline & \multicolumn{2}{|c|}{$\mathrm{BEL}^{2}$} & \multicolumn{2}{|c|}{$\mathrm{TID}^{3}$} & \multirow{2}{*}{$R^{2(5)}$} \\
\hline & $a$ & $\overline{\text { S.D. }{ }^{4}}$ & $b$ & S.D. & \\
\hline Protein & 16.95 & 3.69 & 97.8 & 0.3 & 0.99 \\
\hline \multicolumn{6}{|c|}{ Essential amino acids } \\
\hline Arginine & 1.36 & 0.26 & 99.0 & 3.8 & 0.98 \\
\hline Histidine & 0.18 & 0.10 & 93.0 & 1.9 & 0.99 \\
\hline Lysine & 0.60 & 0.16 & 99.4 & 1.1 & 0.99 \\
\hline Isoleucine & 0.64 & 0.17 & 98.0 & 1.8 & 0.99 \\
\hline Leucine & 0.98 & 0.19 & 99.5 & 1.1 & 0.99 \\
\hline Valine & 0.81 & 0.18 & 98.4 & 1.5 & 0.99 \\
\hline Methionine & 0.35 & 0.09 & 97.0 & 9.0 & 0.99 \\
\hline Phenylalanine & 0.63 & 0.10 & 100.2 & 1.0 & 0.99 \\
\hline Threonine & 0.96 & 0.21 & 96.0 & 2.6 & 0.99 \\
\hline \multicolumn{6}{|c|}{ Non essential amino acids } \\
\hline Alanine & 0.99 & 0.20 & 97.2 & 3.5 & 0.98 \\
\hline Aspartic acid & 1.25 & 0.26 & 97.1 & 2.1 & 0.99 \\
\hline Cystine & 0.30 & 0.07 & 95.3 & 4.8 & 0.96 \\
\hline Glutamic acid & 2.18 & 0.69 & 97.1 & 1.7 & 0.99 \\
\hline Glycine & 0.95 & 0.13 & 99.3 & 3.4 & 0.98 \\
\hline Proline & 0.97 & 0.27 & 98.1 & 1.6 & 0.99 \\
\hline Serine & 0.91 & 0.26 & 95.0 & 2.6 & 0.99 \\
\hline Tyrosine & 0.55 & 0.09 & 100.1 & 1.0 & 0.99 \\
\hline
\end{tabular}

According to equation: $\boldsymbol{Y}=\boldsymbol{a}+\boldsymbol{b} \boldsymbol{X}$.

${ }^{2}$ BEL Basal endogenous losses ( $\boldsymbol{a}=$ intercept, protein or amino acids endogenous losses at ileal level).

${ }^{3}$ TID True ileal digestibility $(\boldsymbol{b}=$ slope, proportion of protein or amino acid that disappeared in the digestive tract, per protein or amino acid unit intake).

${ }^{4} S D$ Standard deviation of the intercept (a) or slope (b).

${ }^{5} \boldsymbol{R}^{2}$ Coefficient of determination for regression straight line.

The difference in the AID of protein between piglets consuming 80 and $240 \mathrm{~g} \mathrm{CP} / \mathrm{kg}$ feed was $9.2 \%$, which was much lower differences in the AIDs of glycine $(66.2 \%)$, arginine (35\%) and alanine (28.2\%) between these groups. The lowest difference in AID between these groups was for Lysine (2.9\%).

\section{TID}

The TID of protein was 97.8, and the average TID for AA was 97.6. The minimum TID value was obtained for histidine (93.0) and the maximum TID value was obtained for phenylalanine (100.2). The TID values for lysine and threonine were 99.4 and 96.0, respectively (Table 4).

\section{Discussion}

In this study, we estimated endogenous protein and AA ileal losses in piglets. Our data demonstrated that endogenous protein was rich in glutamic acid, aspartic acid, and arginine, which represented $32.7 \%$ of endogenous protein loss in weaning piglets. Moreover, the TID 
Table 5 Apparent ileal digestibility

\begin{tabular}{|c|c|c|c|c|c|}
\hline g CP/kg feed & 80 & 160 & 240 & SEM $^{1}$ & $P$ value $^{2}$ \\
\hline Protein $^{A}$ & $82.8^{\mathrm{a}}$ & $86.5^{b}$ & $90.4^{c}$ & 0.06 & 0.001 \\
\hline \multicolumn{6}{|c|}{ Essential amino acids } \\
\hline Arginine $^{A}$ & $62.3^{\mathrm{a}}$ & $73.5^{\mathrm{b}}$ & $84.1^{c}$ & 1.17 & 0.001 \\
\hline Histidine $^{A}$ & $85.5^{\mathrm{a}}$ & $89.0^{\mathrm{b}}$ & $89.8^{\mathrm{b}}$ & 0.71 & 0.05 \\
\hline Lysine $^{\mathrm{A}}$ & $93.4^{\mathrm{a}}$ & $94.5^{\mathrm{ab}}$ & $96.1^{\mathrm{b}}$ & 0.35 & 0.05 \\
\hline Isoleucine ${ }^{A}$ & $85.6^{a}$ & $89.3^{b}$ & $92.6^{c}$ & 0.39 & 0.001 \\
\hline Leucine $^{A}$ & $88.7^{a}$ & $92.0^{\mathrm{b}}$ & $95.1^{c}$ & 0.35 & 0.001 \\
\hline Valine $^{\mathrm{A}}$ & $85.7^{\mathrm{a}}$ & $90.7^{b}$ & $93.1^{c}$ & 0.39 & 0.001 \\
\hline Methionine $^{A}$ & $89.7^{\mathrm{a}}$ & $93.3^{\mathrm{b}}$ & $96.9^{c}$ & 0.42 & 0.001 \\
\hline Phenylalanine $^{A}$ & $88.0^{a}$ & $92.0^{\mathrm{b}}$ & $95.6^{c}$ & 0.38 & 0.001 \\
\hline Threonine $^{\mathrm{A}}$ & $76.7^{a}$ & $80.2^{\mathrm{b}}$ & $86.9^{b}$ & 0.78 & 0.001 \\
\hline \multicolumn{6}{|c|}{ Non essential amino acids } \\
\hline Alanine $^{A}$ & $65.5^{\mathrm{a}}$ & $74.9^{\mathrm{b}}$ & $84.0^{c}$ & 1.09 & 0.001 \\
\hline Aspartic acid ${ }^{\mathrm{A}}$ & $79.5^{\mathrm{a}}$ & $83.9^{\mathrm{b}}$ & $90.0^{c}$ & 0.72 & 0.001 \\
\hline Cystine $^{A}$ & $51.4^{\mathrm{a}}$ & $72.3^{b}$ & $79.5^{\mathrm{b}}$ & 4.26 & 0.01 \\
\hline Glutamic acid ${ }^{\mathrm{A}}$ & $88.1^{\mathrm{a}}$ & $89.8^{\mathrm{a}}$ & $93.4^{b}$ & 0.55 & 0.01 \\
\hline Glycine $^{A}$ & $47.7^{\mathrm{a}}$ & $69.7^{b}$ & $79.3^{c}$ & 1.23 & 0.001 \\
\hline Proline $^{\mathrm{A}}$ & $87.1^{\mathrm{a}}$ & $91.7^{\mathrm{b}}$ & $93.6^{\mathrm{b}}$ & 0.49 & 0.001 \\
\hline Serine $^{A}$ & $78.1^{\mathrm{a}}$ & $82.5^{\mathrm{b}}$ & $87.5^{c}$ & 0.73 & 0.001 \\
\hline Tyrosine ${ }^{A}$ & $88.8^{a}$ & $92.1^{b}$ & $95.7^{c}$ & 0.37 & 0.001 \\
\hline
\end{tabular}

${ }^{1}$ Standard Error of the Mean

2abc Means with different superscript differ at probability level show in the fifth column.

${ }^{\mathrm{A}}$ Linear effect $(P<0.001)$.

of casein was high, varying from 93.0 for histidine to 100.2 for phenylalanine.

\section{lleal losses}

The protein and AA ileal losses found in this study were similar to those reported by Mariscal-Landín and Reis de Souza [6], except that proline losses were higher in the earlier study. This difference was likely to be attributable to the fact that we used higher dietary protein levels and that lysine, methionine, threonine and tryptophan were supplemented to fulfill NRC requirements in the current study [15]. Another reason could be the duration of the experimental period: $7 \mathrm{~d}$ in the current study compared to $14 \mathrm{~d}$ in the previous study. This shorter period was used to avoid increased proline loss caused by prolonged consumption of a low protein diet [9].

AA supplementation and the short period of consumption of the low protein diet could reduce muscle catabolism, thereby decreasing blood glutamine levels. These effects could lead to suppression of proline synthesis because enterocytes use glutamine as proline precursor [25-27]. Moreover, proline synthesis dependent of pyrroline-5-caboxylate, has been associated with increased proline loss in growing pigs fed protein-free diets $[1,8,28]$. Because the activity of pyrroline-5-carboxylate reductase, the enzyme responsible for proline synthesis, is greater than the activity of proline oxidase, the enzyme responsible for proline degradation [1].

The arginine losses reported here agree with the results of some previously reported studies Leibholz [29] and Mariscal-Landín and Reis de Souza [6], but disagree with the results of studies by Eklund $[4,5]$. These differences are likely due to differences in study design; Eklund used during 4 periods of $7 \mathrm{~d}$ each with the same piglets and reported values as the mean of the 4 periods. Our values represented only those obtained during the fourth wk of age, which was also observed in studies by Leibholz [29] and Mariscal-Landin and Reis de Souza [6].

Additionally, the glycine losses reported in our study agree with values reported in 4-wk-old piglets fed a protein-free diet [30] and in 4- and 5-wk-old piglets [6]. Glycine losses are associated with biliary secretion because glycine represents $95 \%$ of amino nitrogen present in biliary salts [31].

\section{Ileal digestibility}

The AID for protein from casein (86.6 on an average) and for AA were similar to those reported by Mariscal-Landín and Reis de Souza [6]. Additionally, the AIDs for glycine, arginine and alanine (47.7, 62.3 and 65.5 respectively) were the most affected by protein levels. Glycine has been reported as the least digestible AA from casein [6,32], as observed in this study, because lacteal proteins, which include casein, have a low glycine content, and glycine endogenous losses are important [30]. Both factors interact to reduce the AID of glycine. Moreover a combination of the same factors could explain the low AID of arginine because lacteal proteins have low arginine content [33] and because endogenous protein is rich in arginine [6,29].

The lack of variation in the AIDs of lysine, histidine, threonine, cystine and proline between treatments (160 and $240 \mathrm{~g} \mathrm{CP} / \mathrm{kg}$ of feed) could be due to the high levels of these AAs in protein. Jørgensen [34] fed growing pigs a casein-based diet $(13 \%, 16 \%, 19 \%$, and $22 \% \mathrm{CP})$ and observed differences between the AIDs of AAs only for pigs fed $13 \%$ and $16 \%$ CP. No differences were observed in groups fed $16 \%, 19 \%$ or $22 \%$ CP. The high TID values (greater than 93.0) were due to high casein digestibility and its low induction of endogenous secretion [35]; because of these characteristics, casein is often used to measure endogenous losses. In our study, the TIDs of AAs were similar to those reported previously $[4,6]$.

\section{Conclusions}

The basal endogenous protein loss in piglets was $16.9 \mathrm{~g} / \mathrm{kg}$ DMI; Endogenous protein was rich in glutamic acid, aspartic acid and arginine, which represented $32.7 \%$ of endogenous protein loss in weaning piglets. The TID of casein was high and varied from 93.0 for histidine to 100.2 for phenylalanine. 


\section{Abbreviations}

AA: Amino acids; AID: Apparent ileal digestibility; TID: True ileal digestibility; BW: Body weight; DM: Dry matter; CP: Crude protein.

\section{Competing interests}

The authors declare that they have no competing interests.

\section{Authors' contributions}

All authors contributed equally to this research. All authors read and approved the final manuscript.

\section{Acknowledgments}

This study was funded in part by the Minister of Agriculture, Livestock and Fishing (SAGARPA) of Mexico and The National Council for Science and Technology (CONACYT) of Mexico via the financial support given to Research Project SAGARPA-CONACYT 2003-2-169.

\section{Author details}

${ }^{1}$ Facultad de Ciencias Naturales, Universidad Autónoma de Querétaro, Santiago de Querétaro, Av. De las Ciencias s/n Juriquilla 76000, Querétaro, Querétaro, México. ${ }^{2}$ Centro Nacional de Investigación en Fisiología Animal, Instituto Nacional de Investigaciones Forestales Agrícolas y Pecuarias, Km 1, Carretera a Colón, Ajuchitlán Colón Querétaro, 76280 México.

Received: 23 April 2013 Accepted: 12 September 2013 Published: 22 September 2013

\section{References}

1. Mariscal-Landín G, Sève B, Collèaux Y, LeBreton Y: Endogenous amino nitrogen collected from pigs with end to end ileorectal anastomosis is affected by the method of estimation and altered by dietary fiber. J Nutr 1995, 125:136-146.

2. Furuya S, Kaji Y: Estimation of the true ileal digestibility of amino acids and nitrogen from their apparent values for growing pigs. Anim Feed SC Technol 1989, 26:271-285.

3. Hodgkinson SM, Souffrant WB, Moughan PJ: Comparison of the enzymehydrolyzed casein, guanidination, and isotope dilution methods for determining ileal endogenous protein flow in the growing rat and pig. J Anim Sci 2003, 81:2525-2534.

4. Eklund M, Mosenthin R, Piepho HP, Rademacher M: Estimates of the basal ileal endogenous losses of amino acids by regression analysis and determination of standardised ileal amino acids digestibilities from casein in newly weaned piglets. J Sci Food Agric 2008, 88:641-651.

5. Eklund M, Mosenthin R, Piepho HP, Rademacher M: Effect of dietary protein crude level on basal ileal endogenous losses and standardized ileal digestibilities of crude protein and amino acids in newly weaned pigs. J Anim Physiol Anim Nutr 2008, 92:578-590.

6. Mariscal-Landín G, Reis de Souza TC: Endogenous ileal losses of nitrogen and amino acids in pigs and piglets fed graded levels of casein. Arch Anim Nutr 2006, 60:454-466.

7. Apolônio LR, Donzele JL, de Oliveira RFM, Silva FCO, Lopes DC, Freitas LS: Digestibilidade ileal de aminoácidos de alimentos utilizados em dietas pré-iniciais para leitões, determinada pelo método do sacrificio. $R$ Bras Zootec 2002, 31:1983-1998.

8. de Lange CFM, Sauer WC, Souffrant WB: The effect of protein status of the pig on the recovery and amino acid composition of endogenous protein in digesta collected from the distal ileum. J Anim Sci 1989, 67:755-762.

9. Hodgkinson SM, Moughan PJ, Reynolds GW: Effect of the duration of feeding of a protein-free diet on endogenous ileal nitrogen and amino acid loss in the growing pig. J Sci Food Agric 2000, 80:1407-1412.

10. Mariscal-Landín G, Reis de Souza TC, Parra SJE, Aguilera BA, Mar BB: lleal digestibility of protein and amino acids from canola meal in weaned piglets and growing pigs. Livest Sci 2008, 116:53-62.

11. Mariscal-Landín G, Reis de Souza TC, Ávalos MA: lleal amino acids digestibility of sorghum in weaned piglets and growing pigs. Animal 2010, 4:1341-1348

12. Diario Oficial de la Federación: Especificaciones técnicas para la producción, cuidado y uso de los animales de laboratorio, Norma Oficial Mexicana NOM-062-ZOO-1999. México D.F: Diario Oficial de la Federación; 2001.

13. International guiding principles for biomedical research involving animals. 1985: . The development of science-based guidelines for laboratory animal care - NCBI Bookshelf. [http://cioms.ch/publications/ guidelines/1985_texts_of_guidelines.htm]

14. Reis de Souza TC, Mar BB, Mariscal LG: Canulación de cerdos posdestete para pruebas de digestibilidad ileal: Desarrollo de una metodología. Téc Pecu Méx 2000, 38:143-150.

15. NRC: Nutrient requirements of swine. 10th edition. Washington, DC: The National Academy Press; 1998.

16. INRA: L'alimentation des animaux monogastriques: porc, lapin, volailles. Paris, France: Institut National de la Recherche Agronomique; 1984.

17. AOAC: Official methods of analysis. 17th edition. Arlington, VA: Assoc. Offic. Anal. Chem.; 2000.

18. Fenton TW, Fenton M: An improved procedure for determination of chromic oxide in feed and feces. Can J Anim Sci 1979, 59:631-634.

19. Henderson JH, Ricker RD, Bidlingmeyer BA, Woodward C: Rapid, accurate and reproducible HPLC analysis of amino acids. Amino acid analysis using Zorbax Eclipse AAA columns and the Agilent 1100 HPLC. USA: Agilent technologies; 2000. Part No5980-1193E 2000:10 pag. Agilent Technologies home page at: www.agilent.com/chem/supplies.

20. Fan MZ, Sauer WC: Determination of apparent ileal amino acid digestibility in barley and canola meal for pigs with the direct, difference, and regression methods. J Anim Sci 1995, 73:2364-2374.

21. Chung TK, Baker DH: Apparent and true amino acid digestibility of a crystalline amino acid mixture and of casein: comparison of values obtained with ileal-cannulated pigs and cecectomized cockerels. J Anim Sci 1992, 70:3781-3790.

22. Urbaityte R, Mosenthin R, Eklund M, Piepho HP, Rademacher M: Determination of standardized ileal crude protein and amino acid digestibilities in protein supplements for piglets. Animal 2009, 3:1696-1705.

23. SAS version 9.2: Book statistical analysis systems institute User's guide. 9.2nd edition. SAS Institute Inc; 2008.

24. Steel RGD, Torrie JH: Principles and procedures of statistics. A biometrical approach. 2nd edition. New York: McGraw-Hill; 1980.

25. Wu G, Davis PK, Flynn NE, Knabe DA, Davidson T: Endogenous synthesis of arginine plays an important role in maintaining arginine homeostasis in postweaning growing pigs. J Nutr 1997, 127:2342-2349.

26. Dekaney CM, Wu G, Jaeger LA: Ornithine aminotransferase messenger RNA expresion and enzymatic activity in fetal porcine intestine. Pediatr Res 2001, 50:104-109.

27. Bertolo RFP, Brunton JA, Pencharz PB, Ball RO: Arginine, ornithine, and proline interconversion is dependent on small intestinal metabolism in neonatal pigs. Am J Physiol Endocrinol Metab 2003, 284:E915-E922.

28. Stein $\mathrm{HH}$, Trottier NL, Bellaver C, Easter RA: The effect of feeding level and physiological status on total flow and amino acid composition of endogenous protein at the distal ileum in swine. J Anim Sci 1999, 77:1180-1187.

29. Leibholz J: The flow of endogenous nitrogen in the digestive tract of young pigs. Br J Nutr 1982, 48:509-517.

30. Darragh AJ, Moughan PJ: The amino acid composition of human milk corrected for amino acid digestibility. Br J Nutr 1998, 80:25-34.

31. Juste $C$ : Apports endogènes par les secretions digestives chez le porc. In Les Colloques de I'INRA. Edited by Laplace JP, Corring T, Rérat A. Paris: INRA; 1982:155-173.

32. Nyachoti CM, de Lange CFM, McBride BW, Schulze H: Significance of endogenous gut nitrogen losses in the nutrition of growing pigs: a review. Can J Anim Sci 1997, 77:149-163.

33. Wu G, Bazer FW, Davis TA, Jaeger LA, Johnson GA, Kim SW, Knabe DA, Meininger CJ, Spencer TE, Yin Y-L: Important roles for the arginine family of amino acids in swine nutrition and production. Livest Sci 2007, 112:8-22.

34. Jørgensen $H$, Gabert VM: The ileal digestion of semipurified diets containing increasing levels of casein and the use of the regression method to estimate the endogenous flow of amino acids at the distal ileum of growing pigs. In Digestive physiology in pigs. Edited by Lindberg JE, Ogle B. New York: CABl publishing; 2001:198-201.

35. Valette P, Malouin H, Corring T, Savoie L, Gueugneau AM, Berot S: Effects of diets containing casein and rapeseed on enzyme secretion from the exocrine pancreas in the pig. Br J Nutr 1992, 67:215-222.

\section{doi:10.1186/2049-1891-4-36}

Cite this article as: Reis de Souza et al:: Estimation of endogenous protein and amino acid ileal losses in weaned piglets by regression analysis using diets with graded levels of casein. Journal of Animal science and Biotechnology 2013 4:36. 